\title{
Risk factors of hepatitis $C$ virus transmission and genotype distribution in former blood donors from Chinese rural area
}

Wenjiao Yin ${ }^{1}$, Changhong Huang ${ }^{2}$, Feng Qiu ${ }^{1}$, Li Liu $^{3}$, Feng Wang ${ }^{1}$, Jikun Zhou ${ }^{3}$, Yong Zhang ${ }^{1,4^{*}}$ and Shengli Bi $i^{1,4^{*}}$

\begin{abstract}
Background: Illegal commercial plasma and blood donation activities in the late 1980s and early 1990s caused a large number of hepatitis $C$ virus (HCV) infections in rural areas of China. In the present study, we aimed to elucidate the risk factors of HCV RNA positivity and HCV genotype distribution in former blood donors.

Methods: A cross-sectional survey was carried out in a former blood donation village in rural Hebei Province, North China. All residents were invited for a questionnaire interview and testing for HCV antibodies as well as HCV nucleic acids. Questionnaires were administered to collect information about their personal status and commercial blood donation history. Nested PCR was used to amplify HCV nucleic acids in C/E1 region and NS5b region followed by genotyping and phylogenetic analysis. Univariate and multivariate logistic regression were used to analyze the distributions of HCV genotypes in different groups.
\end{abstract}

Results: A total of 512 blood samples were collected. Anti-HCV positive were 148 (28.5\%) whereas RNA positive rate was $13.87 \%$. Residents between 50 and 59 years old had the highest RNA positive rate $(27 / 109,24.77 \%)(P=0.0051)$. Multivariate logistic regression model analysis revealed that plasma donation $(\mathrm{OR}=8.666,95 \% \mathrm{Cl}:$ 1.390-54.025) was the dominant risk factor of HCV infection. Furthermore, HCV subtypes $1 \mathrm{~b}$ and $2 \mathrm{a}$ were found by genotyping and phylogenetic analysis. 36 samples (53.73\%) were subtype $1 \mathrm{~b}$ and 31 samples (46.27\%) were subtype $2 \mathrm{a}$.

Conclusions: Unsafe practices during illegal plasma donation led to a high risk of HCV infection. The identification of genotypes $1 \mathrm{~b}$ and $2 \mathrm{a}$ as major HCV genotypes circulating in this region may help to predict the future burden of HCV related diseases and facilitate better medical treatment towards HCV carriers. These results are useful for public healthcare as well as disease control and surveillance.

Keywords: Hepatitis C virus, Blood donor, Risk factor, Phylogenetic tree

\section{Background}

The hepatitis C virus (HCV) can cause hepatitis C, which can range in severity from a mild illness to lifelong diseases including liver cirrhosis or liver cancer [1]. About 130 to 170 million people are chronically infected with $\mathrm{HCV}$ worldwide [2,3]. In China, two nationwide sero-epidemiological studies were conducted. According to the latest investigation in 2006, the overall HCV prevalence in the population of 1-59 years old was

\footnotetext{
*Correspondence: zycdchp@sina.com; shengli_bi@163.com

'Department of Viral Hepatitis, National Institute for Viral Disease Control and Prevention, Chinese Center for Disease Control and Prevention, Beijing, China ${ }^{4}$ Institute for Viral Disease Control and Prevention, Chinese Center for Disease Control and Prevention, Changping District, Beijing 102206, PR China Full list of author information is available at the end of the article
}

0.43\% (95\% CI: 0.33-0.53\%), with about 4.29-6.89 million people estimated to be infected with $\mathrm{HCV}$ throughout China $[4,5]$.

Hepatitis $C$ virus is a single-stranded and positivestrand RNA virus. It is divided into six genotypes [6], which differ from each other by $31-33 \%$ at the nucleotide level. In addition, there are several subtypes with 20-25\% differences [7]. The distribution of genotypes and subtypes varies geographically. For example, genotype $1 \mathrm{~b}, 2 \mathrm{a}$ and $2 \mathrm{~b}$ are widely distributed worldwide [8] whereas genotype 3 is mostly distributed in Indian subcontinent $[9,10]$. Genotype 4 is found in central Africa [11], genotype 5 is found in South Africa and genotype 6 is found in South Asia [12]. In China, studies have 
shown that genotypes $1 \mathrm{~b}$ and $2 \mathrm{a}$ are the predominant HCV subtypes [13-15] and other subtypes (3a, 3b, 6a, $6 \mathrm{n}$ and $6 \mathrm{u}$ ) were reported from southwest part of China $[16,17]$.

Many residents in China rural areas were infected with HCV due to blood selling in the late 1980s. Although a previous study showed that the history of paid plasma donation was responsible for the high sero-prevalence of $\mathrm{HCV}$ in a village in rural Hebei Province, North China [18], little is known about the HCV RNA positivity and genotypes distribution in these blood donors. In the present study, we aimed to elucidate the risk factors for HCV RNA positivity and HCV genotypes distribution. The results may provide important information for future treatment of $\mathrm{HCV}$ related diseases and facilitate better public health control and surveillance.

\section{Methods}

\section{Ethics statement}

The survey protocol conformed to the ethical guidelines of the 1975 Declaration of Helsinki and was approved by the Ethics Committee in Chinese National Institute for Viral Disease Control and Prevention. The written informed consent of adults and permission from the parents of minors were obtained before the interview and venous blood collection.

\section{Questionnaire interview and serum sampling}

The questionnaire included demographic characteristics of the subjects and exposure histories for possible risk factors related to HCV infection. Five milliliters of venous blood was then collected from each subject and the serum separated. Serum samples were stored at $-20^{\circ} \mathrm{C}$. A total of 520 residents were interviewed and 512 subjects accepted for venous blood collection. These subjects included former blood donors as well as nonblood donors, ranged in age from 3 to 89 years old; 261 were female $(261 / 512,50.98 \%)$ and 251 were male (251/ $512,49.02 \%)$.

\section{Extraction and amplification of HCV RNA C/E1 region and NS5b region}

HCV RNA was extracted from $140 \mu$ l serum with QIAamp Viral RNA Mini Kit (Qiagen, Hilden, Germany). HCV RNA positivity was identified by nested PCR based on C/E1 fragment. The PCR products were detected by $1 \%$ agarose gel electrophoresis for qualitative analysis. In addition, HCV genotypes and subgenotypes were determined by using nested PCR and sequencing. Briefly, two fragments corresponding to the HCV genome sequence nt 845-1315 on H77 (fragment C/E1) and nt 8254-8636 (fragment NS5b), were amplified respectively. A typical amplification procedure was performed in a $50 \mu \mathrm{l}$ reaction volume containing $5 \mu \mathrm{l}$ extracted $\mathrm{HCV}$ RNA and Taq polymerase for 35 cycles, denaturing for $30 \mathrm{~s}$ at $94^{\circ} \mathrm{C}$, annealing for $30 \mathrm{~s}$ at $58^{\circ} \mathrm{C}$, and elongation for $35 \mathrm{~s}$ at $72^{\circ} \mathrm{C}$, followed by a final extension at $72^{\circ} \mathrm{C}$ for $10 \mathrm{~min}$. Standard precautions to avoid contamination during PCR were taken, including a negative control serum in each run. The primers used for the amplification of fragment $\mathrm{C} / \mathrm{E} 1$ and fragment NS5b was listed in Table 1.

\section{Nucleotide sequencing of PCR products}

The positive amplification products identified by agarose gel electrophoresis were sequenced directly by the dideoxy termination method using the Big Dye Terminator cycle sequencing Ready Reaction Kit ver. 3.1 (Applied Biosystems, Foster City, CA) with modifications and an automatic sequencer (ABI PRISM 3100 Genetic Analyser; Applied Biosystems). PCR products were sequenced in forward and reverse directions. Sequence alignment was performed by using the multiple-alignment algorithm in MegAlign software (DNASTAR, Windows version 5.06, WI).

\section{$\mathrm{HCV}$ genotyping and phylogenetic analysis}

The PCR product of fragment C/E1 was $471 \mathrm{bp}$ and that of fragment NS5b was $383 \mathrm{bp}$. The nucleotide sequences obtained were aligned with HCV strains of standard genotypes by the ClustalW method of MEGA software (Version 4.0), and the Neighbor-Joining method was used to construct a phylogenetic tree to determine the genotypes of our samples.

\section{Statistical analysis}

Univariate and multivariate logistic regression were used to analyze associations between $\mathrm{HCV}$ RNA positivity and risk factors. Statistical analysis was performed using SAS 9.1 (Statistical Analysis Software Institute Inc, USA).

\section{Results}

Risk factor analysis of HCV RNA positivity in former blood donors

HCV RNA positivity was found in 71 (71/512, 13.87\%) of the participants, with 37 (37/261, 14.18\%) females and 34 $(34 / 251,13.55 \%)$ males. There was no statistical difference between male and female $(P=0.8365)$. However, there were significant differences between age groups $(\mathrm{P}=0.0051)$. The prevalence of HCV RNA positivity was $2.08 \%$ in $3-19$ years age group, $9.52 \%$ in $20-29$ years age group, $6.78 \%$ in $30-39$ years age group, $14.06 \%$ in $40-49$ years age group, $24.77 \%$ in $50-59$ years age group and $14.29 \%$ in $>60$ years age group. Furthermore, there was a statistically higher prevalence in married people $(68 / 449$, $15.14 \%)$, compared to unmarried people $(3 / 63,4.76 \%)$ $(\mathrm{P}=0.0358)$. There was no significant difference by occupation $(\mathrm{P}=0.094)$, as the prevalence was $16.88 \%$ in 
Table 1 Details of the primers for HCV amplification

\begin{tabular}{llll}
\hline Targeted fragment & Name & Sequence of oligonucleotide (5'-3') & Position (on H77) \\
\hline Fragment C/E1 & C/E1-F1 & ACTGCCTGATAGGGTGCTTGC & $288-308$ \\
& C/E1-R1 & GGTGACCAGTTCATCATCATATCC & $1301-1324$ \\
C/E1-F2 & CCTTCCTGGTTGCTCTTTCTCTAT & $845-868$ \\
Fragment NS5b & G/E1-R2 & CCAATTWTCATCATATCCCAAGCCAT & $1293-1315$ \\
& NS5b-F1 & TGGRGTGTGTCKDGCTGTTTCC & $7995-8017$ \\
& NS5b-R1 & CGTATGATACCCGCTGTTTGA & $8789-8810$ \\
& NS5b-F2 & CCTGGTCATAGCCTCCGTGAA & $8254-8275$ \\
& NS5b-R2 & & $8616-8636$ \\
\hline
\end{tabular}

peasants, $10.17 \%$ in students, $6.25 \%$ in preschool children, and $8.55 \%$ in people whose occupation were unknown. There was also no statistical difference by education degree $(\mathrm{P}=0.2540)$, as the prevalence was $19.80 \%$ in illiterate people, $15.60 \%$ in primary school level, $13.04 \%$ in junior high school level, $15.63 \%$ in senior high school level, 6.67\% in kindergarten level, and $8.55 \%$ in people whose education level was unknown (Table 2).

In regard to risk behavior variables and HCV infection, it was important to note that the selling of blood was prominent in this district in the late 1980s. Two types of blood selling were found in this village, the selling of whole blood and the selling of plasma. The results of our questionnaire indicated 232 people had a history of selling whole blood or plasma, with 50 serum samples (50/232, 21.55\%) positive for HCV RNA. According to the types of blood selling, HCV RNA positivity was detected in 7 subjects $(7 / 113,6.19 \%)$ who had sold whole blood, 2 subjects $(2 / 5,40.00 \%)$ who had sold plasma, 41 subjects $(41 / 114,35.96 \%)$ who had sold whole blood and plasma, and 21 subjects $(21 / 280,7.5 \%)$ who had neither sold blood nor plasma. In contrast, histories of blood transfusion, toothbrush sharing, razor sharing, therapeutic injection, acupuncture, surgical operations, or tooth extraction were not risk indicators for HCV RNA positivity in our analysis $(\mathrm{P}>0.05)$ (Table 2$)$.

From a multivariate logistic regression model of $\mathrm{HCV}$ RNA positivity, histories of plasma donation $(\mathrm{OR}=8.666$, 95\% CI: $1.390-54.025)$ and mixed donation (OR $=7.402$, 95\% CI: 4.301-12.740) were risk factors for HCV RNA positivity (Table 3 ).

\section{HCV genotype distribution and phylogenetic analysis}

Sequencing based on C/E1 region and NS5b region of $\mathrm{HCV}$ genome and the phylogenetic analysis were performed successfully for $67 \mathrm{HCV}$ RNA-positive samples. The results demonstrated that 36 strains (36/67, 53.73\%) were closely related to subtype $1 \mathrm{~b}$, and 31 strains $(31 / 67$, $46.27 \%$ ) belonged to subtype $2 \mathrm{a}$. In genotype $1 \mathrm{~b}$ isolates, ZX2005-229 was highly homologous with reference strain
AY835056 which was isolated in Kunming in 2005. Comparatively, ZX2005-321 in 2a isolates was strongly consistent with AY834956 which was a Beijing HCV strain with 99\% homology. The mean pairwise distance of these 67 strains was 0.544 substitutions per nucleotide site, with 0.060 in genotype $1 \mathrm{~b}$ strains and 0.030 in genotype $2 \mathrm{a}$ strains, respectively (Figures 1 and 2).

The phylogenetic tree based on $\mathrm{HCV} \mathrm{C/E1} \mathrm{sequences}$ and NS5b sequences demonstrated that 36 strains were closely related to subtype $1 \mathrm{~b}$ and 31 strains belonged to subtype 2a. $\boldsymbol{\Delta}$ denotes the reference isolates and the bootstrap values were added. denotes that a HBV strain (accession number: AF121250 \& AB073821) was used as an out-group.

Furthermore, all HCV isolates discovered in this study were uploaded to NCBI website and the Accession Numbers released by NCBI were: KP721870 to KP721938 for sequences from the amplification of $\mathrm{C} / \mathrm{E} 1$ region and KP721803 to KP721869 for sequences of NS5b region respectively (Additional file 1).

By using NCBI BLAST, it was indicated that for genotype 1 b strains, 16 strains $(16 / 36,44.44 \%)$ were closely related to isolate $\mathrm{km} 48$ (accession number: AY835056), with $97-99 \%$ homology, 3 strains were related to isolate HC-P32(accession number: AF046186), 3 strains were related to isolate $\mathrm{HC}-\mathrm{C} 2$ (accession number: D10934), and the remaining 14 strains were related to other isolates. For genotype 2a strains, 27 strains (27/31, 87.10\%) were closely related to isolate bj779 (accession number: AY834956), with 96-99\% homology, 4 strains (4/31, 12.90\%) were closely related to isolate ZS199 (accession number: JX677261), GZ302 (accession number: JX521943), ZS37 (accession number: JX677354) or P012-NL(AE)_2a_1977.7 (accession number: JF722462).

Further analysis indicated HCV genotype distribution in gender and age groups. Briefly, in females, 14 strains $(14 / 34,41.18 \%)$ belonged to genotype $1 \mathrm{~b}$, and 20 strains $(20 / 34,58.82 \%)$ belonged to genotype 2a; however, 22 strains $(22 / 33,66.67 \%)$ belonged to genotype $1 \mathrm{~b}$, and 11 strains $(11 / 33,33.33 \%)$ belonged to 
Table 2 Univariate analysis of HCV RNA positivity and related factors

\begin{tabular}{|c|c|c|c|c|c|}
\hline Variable & No. of samples & No. of positive & Positive rate (\%) & OR $(95 \% \mathrm{Cl})$ & $P$ value \\
\hline Sex & & & & & 0.8365 \\
\hline Female & 261 & 37 & 14.18 & Reference & \\
\hline Male & 251 & 34 & 13.55 & $0.949(0.574,1.567)$ & \\
\hline Age group & & & & & 0.0051 \\
\hline $3-19$ years & 48 & 1 & 2.08 & Reference & \\
\hline 20-29 years & 63 & 6 & 9.52 & $4.947(0.575,42.555)$ & \\
\hline 30-39 years & 59 & 4 & 6.78 & $3.418(0.369,31.650)$ & \\
\hline 40-49 years & 128 & 18 & 14.06 & $7.691(0.998,59.292)$ & \\
\hline $50-59$ years & 109 & 27 & 24.77 & $15.476(2.037,117.583)$ & \\
\hline 60 years or older & 105 & 15 & 14.29 & $7.833(1.004,61.138)$ & \\
\hline Marriage status & & & & & 0.0358 \\
\hline unmarried & 63 & 3 & 4.76 & Reference & \\
\hline married & 449 & 68 & 15.14 & $3.570(1.088,11.709)$ & \\
\hline Occupation & & & & & 0.0940 \\
\hline Peasant & 320 & 54 & 16.88 & Reference & \\
\hline Student & 59 & 6 & 10.17 & $0.558(0.228,1.363)$ & \\
\hline Preschool child & 16 & 1 & 6.25 & $0.328(0.042,2.539)$ & \\
\hline Unknown & 117 & 10 & 8.55 & $0.460(0.226,0.937)$ & \\
\hline Education degree & & & & & 0.2540 \\
\hline Illiterate & 101 & 20 & 19.80 & Reference & \\
\hline Primary school & 109 & 17 & 15.60 & $0.748(0.367,1.526)$ & \\
\hline Junior high school & 138 & 18 & 13.04 & $0.607(0.303,1.219)$ & \\
\hline Senior high school & 32 & 5 & 15.63 & $0.750(0.257,2.192)$ & \\
\hline Kindergarten & 15 & 1 & 6.67 & $0.289(0.036,2.332)$ & \\
\hline Unknown & 117 & 10 & 8.55 & $0.379(0.168,0.853)$ & \\
\hline Whole blood donation & & & & & 0.0102 \\
\hline No & 399 & 64 & 16.04 & Reference & \\
\hline Yes & 113 & 7 & 6.19 & $0.346(0.154,0.777)$ & \\
\hline Plasma donation & & & & & 0.1177 \\
\hline No & 507 & 69 & 13.61 & Reference & \\
\hline Yes & 5 & 2 & 40.00 & $4.232(0.695,25.785)$ & \\
\hline Mix donation* & & & & & $<0.0001$ \\
\hline No & 398 & 30 & 7.54 & Reference & \\
\hline Yes & 114 & 41 & 35.96 & $6.889(4.040,11.748)$ & \\
\hline Blood transfusion & & & & & 0.6913 \\
\hline No & 507 & 70 & 13.81 & Reference & \\
\hline Yes & 5 & 1 & 20.00 & $1.563(0.172,14.175)$ & \\
\hline Tooth-brush share & & & & & 0.5269 \\
\hline No & 508 & 70 & 13.78 & Reference & \\
\hline Yes & 4 & 1 & 25.00 & $2.086(0.214,20.334)$ & \\
\hline Razor share & & & & & 0.9739 \\
\hline No & 505 & 70 & 13.86 & Reference & \\
\hline Yes & 7 & 1 & 14.29 & $1.036(0.123,8.734)$ & \\
\hline
\end{tabular}


Table 2 Univariate analysis of HCV RNA positivity and related factors (Continued)

\begin{tabular}{|c|c|c|c|c|c|}
\hline Therapeutic injection & & & & & 0.5103 \\
\hline No & 478 & 65 & 13.60 & Reference & \\
\hline Yes & 34 & 6 & 17.65 & $1.362(0.543,3.416)$ & \\
\hline Acupuncture & & & & & 0.3609 \\
\hline No & 493 & 67 & 13.59 & Reference & \\
\hline Yes & 19 & 4 & 21.05 & $1.696(0.546,5.263)$ & \\
\hline Surgery operation & & & & & 0.3566 \\
\hline No & 435 & 58 & 13.33 & Reference & \\
\hline Yes & 77 & 13 & 16.88 & $1.363(0.706,2.634)$ & \\
\hline Tooth extraction & & & & & 0.8907 \\
\hline No & 469 & 65 & 13.86 & Reference & \\
\hline Yes & 43 & 6 & 13.95 & $1.065(0.431,2.633)$ & \\
\hline
\end{tabular}

*Note: Mix donation denotes whole blood donation and plasma donation.

genotype $2 \mathrm{a}$ in males. The distribution of HCV genotypes statistically differed by gender $\left(x^{2}=4.3767\right.$, $\mathrm{P}=0.0364$ ), but did not significantly differ by age (Fisher's Exact Test, $\mathrm{P}=0.7987$ ).

\section{Discussion}

The total HCV RNA positive rate was much higher in the village examined compared to the general Chinese population $[4,5]$ due to illegal blood donation that prevailed in some areas of Hebei province in the late 1980s $[19,20]$. According to results from a logistic regression model for HCV RNA positivity, illegal blood donation, especially plasma donation, probably led to the high positive rate of HCV RNA. Plasma donation is a blood collection method in which plasma is separated by centrifugation and the remaining cells transfused back into donors. This process could easily cause cross-infection due to the poor disinfection of blood collectors and substandard aseptic technology. Importantly, the HCV RNA positive rate of plasma donors was $40 \%$ and the mixed donors who sold whole blood and plasma had a rate of $35.96 \%$. In the middle 1990s, the Chinese government enacted laws to ban this type of blood donation.

Table 3 Logistic regression of multi-risk factors for HCV RNA positivity

\begin{tabular}{lll}
\hline Variable & OR $(\mathbf{9 5 \%} \mathbf{C l})$ & $\boldsymbol{P}$ value \\
\hline Plasma donation & & 0.0207 \\
No & Reference & \\
Yes & $8.666(1.390,54.025)$ & \\
Mix donation* & & \\
No & Reference & \\
Yes & $7.4002(4.301,12.740)$ & \\
\hline
\end{tabular}

*Note: Mix donation denotes whole blood donation and plasma donation.
Although illegal blood collection agencies in this region were banned, the prevalence of HCV RNA was still high because of the chronic infection of HCV. Males and females had an equal positive rate of HCV RNA, which could reflect their common behavior in selling blood. Males and females typically sold blood together and thus had an equal risk of being infected by blood-borne viruses.

Classified by age, residents 50-59 years old had the highest positive rate of HCV RNA, whereas the 3-19 year old population had the lowest. Blood donors in the late 1980s were mostly young adults responsible for supporting families; therefore, they usually sold their blood because of their poverty and low literacy.

HCV subtype 1b was predominant in this village and the next prevalent genotype was $2 \mathrm{a}$. Other subtypes were not found in this study. Previous studies showed that genotypes $1 \mathrm{~b}$ and $2 \mathrm{a}$ are dominant in China, and some studies reported the presence of genotypes $6 \mathrm{a}$ and $3 \mathrm{~b}$ in southern China [13-15]. The village in this study was located in Hebei Province in northern China. In the late 1980s, many illegal blood agencies set up blood collection sites in this village and many local peasants went there to sell blood. We speculate that HCV subtype $1 \mathrm{~b}$ and $2 \mathrm{a}$ were transmitted in this village and nearby regions. Cross infection during the blood drawing process likely caused the transmission of different HCV subtypes. Reports have indicated that patients with $\mathrm{HCV}$ genotype $1 \mathrm{a}$ or $1 \mathrm{~b}$ had more severe liver disease and lower response rates to interferon therapy than patients with $\mathrm{HCV}$ genotype $2 \mathrm{a}$ or $2 \mathrm{~b}$ [17]. Compared to genotype $1 \mathrm{~b}$, genotype $2 \mathrm{a}$ may be easier to clear spontaneously or by antiviral treatment. This may partly explain why the proportion of genotype $1 \mathrm{~b}$ was slightly higher than genotype $2 \mathrm{a}$.

Interestingly, HCV subtype $2 \mathrm{a}$ was predominant in females and subtype $1 \mathrm{~b}$ was predominant in males. The 


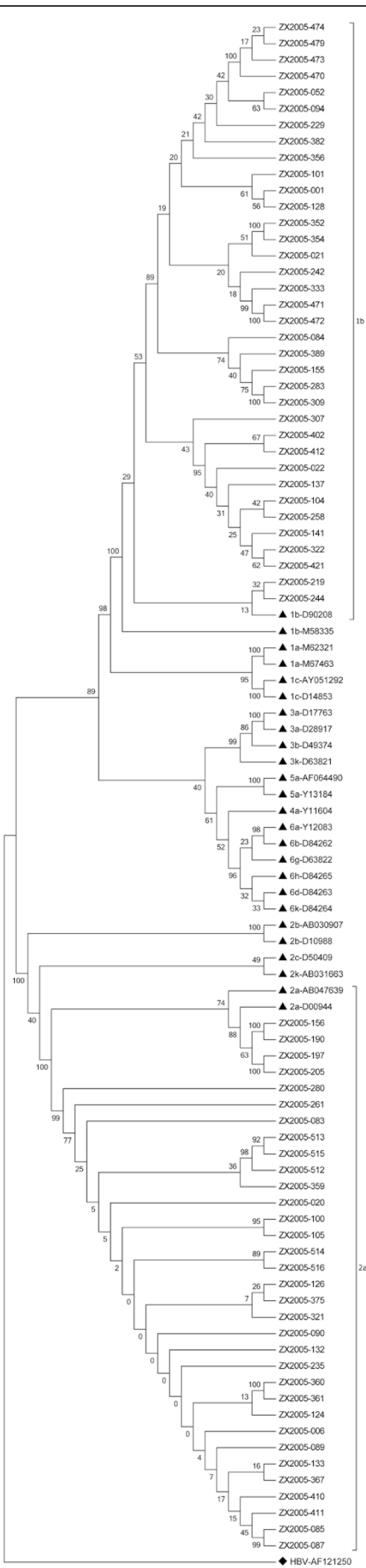

Figure 1 Phylogenetic tree of HCV C/E1 sequences.

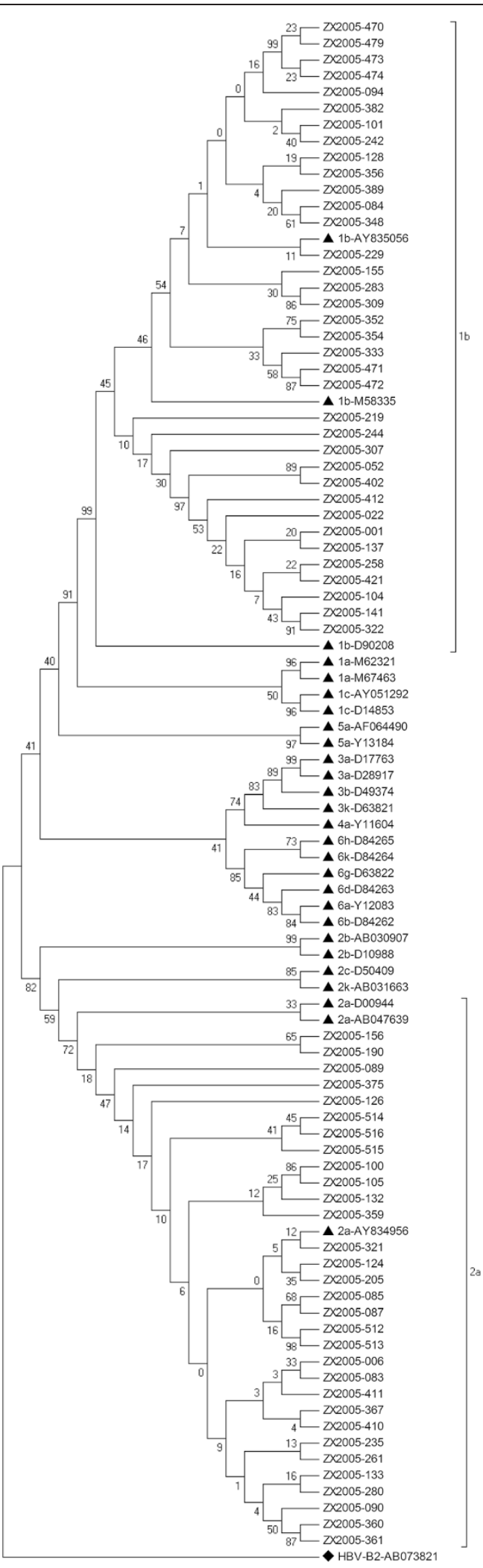

Figure 2 Phylogenetic tree of HCV NS5b sequences. 
cause of this kind of distribution is unknown, but there are two possibilities, firstly, only $\mathrm{HCV}$ RNA positive samples were genotyped and may have limited sample size. Secondly, females may be more susceptible to subtype $2 \mathrm{a}$ and males more vulnerable to subtype $1 \mathrm{~b}$ though this latter hypothesis is highly speculative.

More than $40 \%$ of subtype $1 \mathrm{~b}$ samples were closely related to isolate $\mathrm{km} 48$, and 3 strains were closely related to isolate HC-C2 [21]. Similar to previous studies [13-15], we speculate that subtype $1 \mathrm{~b}$ strains in our study may be widely distributed in China. Compared to subtype 2a strains in our study, the mean pairwise distance was higher, which indicated the genetic diversity of subtype $1 \mathrm{~b}$ samples in this village.

We believe most of our 2a strains may have a common origin with isolate bj779 which was isolated from a subject in Beijing because about $87.10 \%$ of the subtype $2 \mathrm{a}$ strains were closely related to isolate bj779, with a mean pairwise distance of only 0.030 . We also speculate that subtype 2a strains similar to the isolates in our study may be widely distributed in China [22].

\section{Conclusion}

In conclusion, unsafe practices during illegal plasma donation led to a high risk of $\mathrm{HCV}$ infection. The present epidemiological investigation may help to predict the future burden of $\mathrm{HCV}$ related diseases and facilitate better public health control and surveillance. Presently, those residents positive for HCV RNA need urgent medical assistance. The identification of genotypes $1 \mathrm{~b}$ and $2 \mathrm{a}$ as major $\mathrm{HCV}$ genotypes circulating in this region represents valuable information for future medical treatment. It is desirable that China government may provide financial support and free healthcare to these villages, because most of the residents in this rural district make their living by farming and have no stable economic resources.

\section{Additional file}

Additional file 1: NCBI accession numbers of the HCV C/E1 and

NS5b sequences isolated in this study.

\section{Abbreviations}

HCV: Hepatitis C virus; PCR: Polymerase chain reaction.

\section{Competing interests}

The authors declare that they have no competing interests.

\section{Authors' contributions}

Conceived and designed the experiments: YZ, JZ, SB. Performed the experiments: $\mathrm{CH}$. Analyzed the data: WY, CH, FW. Contributed reagents/ materials/analysis tools: LL. Wrote the manuscript: WY, FQ. All authors read and approved the final manuscript.

\section{Acknowledgments}

This work was supported by the Chinese Twelfth Five Year Major Science and Technology Program for Hepatitis (grant number 2012ZX10002001-005-001).
The authors expressed their sincere thanks to the health workers of the Zhao county CDC for their participation in the study.

\section{Author details}

${ }^{1}$ Department of Viral Hepatitis, National Institute for Viral Disease Control and Prevention, Chinese Center for Disease Control and Prevention, Beijing, China. ${ }^{2}$ Kaifeng Center for Disease Control and Prevention, Kaifeng, Henan Province, China. ${ }^{3}$ Shijiazhuang Center for Disease Control and Prevention, Shijiazhuang, Hebei Province, China. ${ }^{4}$ Institute for Viral Disease Control and Prevention, Chinese Center for Disease Control and Prevention, Changping District, Beijing 102206, PR China.

Received: 17 October 2014 Accepted: 13 February 2015

Published online: 25 February 2015

\section{References}

1. Hoofnagle $\mathrm{JH}$. Hepatitis C: the clinical spectrum of disease. Hepatol. 1997:26:15-20

2. Mast EE, Alter MJ, Margolis HS. Strategies to prevent and control hepatitis B and C virus infections: a global perspective. Vaccine. 1999;17:1730-3.

3. Lavanchy D. The global burden of hepatitis C. Liver Int. 2009;29:74-81.

4. Xia GL, Liu CB, Cao HL, Bi SL, Zhan MY, Su CA. Prevalence of hepatitis B and $C$ virus infections in the general Chinese population. Results from a nationwide cross-sectional seroepidemiologic study of hepatitis $A, B, C, D$, and $E$ virus infections in China, 1992. Int Hepatol Commun. 1996;5:62-73.

5. Chen YS, Li L, Cui FQ, Xing WG, Wang L, Jia ZY. A sero-epidemiological study on hepatitis C in China. Chin J Epidemiol. 2011;32:888-91.

6. Ohno O, Mizokami M, Wu RR, Saleh MG, Ohba K, Orito E. New hepatitis $\mathrm{C}$ virus (HCV) genotyping system that allows for identification of HCV genotypes 1a, 1b, 2a, 2b, 3a, 3b, 4, 5a, and 6a. J Clin Microbiol. 1997:35:201-7.

7. Simmonds P, Bukh J, Combet C, Deléage G, Enomoto N, Feinstone S. Consensus proposals for a unified system of nomenclature of hepatitis $C$ virus genotypes. Hepatol. 2005;42:962-73.

8. Huy TT, Abe K. Molecular epidemiology of hepatitis B and C virus infections in Asia. Pediatr Int. 2004;46:223-30.

9. Das B, Kundu B, Khandapkar R, Sahni S. Geographical distribution of hepatitis C virus genotypes in India. Indian J Pathol Microbiol. 2002;45:323.

10. Shah HA, Jafri W, Malik I, Prescott L, Simmonds P. Hepatitis C virus (HCV) genotypes and chronic liver disease in Pakistan. J Gastroenterol Hepatol. 1997:12:758-61.

11. Xu LZ, Larzul D, Delaporte E, Bréchot C, Kremsdorf D. Hepatitis C virus genotype 4 is highly prevalent in central Africa (Gabon). J Gen Virol. 1994;75:2393-8.

12. Smuts $\mathrm{H}$, Kannemeyer J. Genotyping of hepatitis $\mathrm{C}$ virus in South Africa. J Clin Microbiol. 1995;33:1679-81.

13. Lu L, Nakano T, He Y, Fu Y, Hagedorn CH, Robertson BH. Hepatitis C virus genotype distribution in China: predominance of closely related subtype $1 \mathrm{~b}$ isolates and existence of new genotype 6 variants. J Med Virol. 2005;75:538-49.

14. Zhang LQ, Chen ZW, Cao YZ, Yu J, Li GH, Yu WJ. Molecular characterization of human immunodeficiency virus type 1 and hepatitis $C$ virus in paid blood donors and injection drug users in China. J Virol. 2004;78:13591-9.

15. Chen YD, Liu MY, Yu WL, Li JQ, Peng M, Dai Q. Hepatitis C virus infections and genotypes in China. Hepatobiliary Pancreat Dis Int. 2002:1:194-201.

16. Xia XS, Lu L, Tee KK, Zhao WH, Wu JG, Yu J. The unique HCV genotype distribution and the discovery of a novel subtype $6 \mathrm{u}$ among IDUs co-infected with HIV-1 in Yunnan, China. J Med Virol. 2008;80:1142-52.

17. Alexopoulou A, Karayiannis P. Interferon-based combination treatment for chronic hepatitis $C$ in the era of direct acting antivirals. Ann Gastroenterol. 2015:28:55-65.

18. Huang CH, Qiu F, Guo MZ, Yi Y, Shen LP, Wang F. Prevalence and risk factors of hepatitis $C$ among former blood donors in rural China. Int J Infect Dis. 2012;16:e731-4.

19. Sun YD, Meng ZD, Wang SY, Chen XR, Sun DG, Chen Z. Epidemiologic investigation on an outbreak of hepatitis C. Chin Med J. 1991;104:975-9.

20. Meng ZD. A serological study on hepatitis $C$ infection in plasma donors. Chin J Prev Med. 1990;24:193-5 
21. Wang Y, Okamoto H, Tsuda F, Nagayama R, Tao QM, Mishiro S. Prevalence, genotypes, and an isolate ( $\mathrm{HC}-\mathrm{C} 2$ ) of hepatitis $\mathrm{C}$ virus in Chinese patients with liver disease. J Med Virol. 1993;40:254-60.

22. Rao HY, Wei L, Lopez-Talavera JC, Shang J, Chen H, Li J. Distribution and clinical correlates of viral and host genotypes in Chinese patients with chronic hepatitis C virus infection. J Gastroenterol Hepatol. 2013;29:545-53.

Submit your next manuscript to BioMed Central and take full advantage of:

- Convenient online submission

- Thorough peer review

- No space constraints or color figure charges

- Immediate publication on acceptance

- Inclusion in PubMed, CAS, Scopus and Google Scholar

- Research which is freely available for redistribution 